\title{
PENYULUHAN PENYAKIT KULIT DAMPAK BANJIR DI DESA LIANG JULANG BLOK DUKUH DOMBA
}

\author{
Yeti Yuwansyah \\ STIkes YPIB Majalengka \\ yetiyuwansyah@gmail.com
}

\begin{abstract}
The flood disaster that hit several places in Majalengka district in mid February 2021 caused not only damaging property but also physically and mentally. Anjun village, located in Kadipaten sub-district, was one of the affected villages that suffered from skin diseases (phlegm, ringworm and other skin diseases) as a result of physical damage from the flood. Therefore, the community service team of STIKes YPIB had collaborated with the Kadipaten Community Health Center to carry out counseling about skin diseases and how to treat them. This collaborative community service aimed at increasing knowledge about skin diseases and treatment of skin diseases to those who have been infected. The result of this activity is that floodaffected victims can increase their knowledge about skin diseases, treat their skin and heal their own skin diseases. The conclusion of this activity is the collaborative counseling effectively increases the knowledge of flood-affected residents about post-flood skin diseases.
\end{abstract}

Keywords: Counseling; skin disease; flood impact

\begin{abstract}
Abstrak
Bencana banjir yang melanda beberapa tempat di kabupaten Majalengka salah satunya di desa Anjun Kecamatan Kadipaten pada pertengahan Februari 2021 menyebabkan kerusakan harta benda, fisik dan mental. Secara fisik mereka mengalami penyakit kulit (panu,kadas kurap dan penyakit kulit lainya) akibat dari dampak banjir tersebut, sehingga kami bekerjasama dengan puskesmas Kadipaten untuk melaksanakan penyuluhan tentang penyakit kulit dan pengobatan penyakit kulit dari pihak puskesmas. Pengabdian kepada masyarakat ini diberikan bertujuan untuk menambah pengetahuan tentang penyakit kulit dan pengobatan penyakit kulit kepada yang sudah terjangkit. Hasil dari kegiatan ini adalah korban yang terdampak banjir dapat menambah pengetahuan tentang penyakit kulit dan menyembuhkan penyakit kulit yang dideritanya. Kesimpulan dari kegiatan ini adalah penyuluhan dapat meningkatkan pengetahuan masyarakat tentang penyakit kulit akibat dampak banjir.
\end{abstract}

Kata Kunci: Penyuluhan;penyakit kulit;dampak banjir

$$
\text { Submitted: 2021-06-08 }
$$$$
\text { Revised: 2021-07-10 }
$$$$
\text { Accepted: 2021-07-31 }
$$

\section{Pendahuluan}

Banjir di Majalengka terjadi di 3 kecamatan. Di daerah ini pun hujan dengan intensitas tinggi menyebabkan Sungai Cideut dan Situ Cijingga, meluap. Debit dari Sungai Cimanuk juga disebut menyumbang banjir di Majalengka. Tanggul Sungai Cimanuk di daerah ini dilaporkan jebol. Tinggi air bervariasi 15-150 sentimeter. Banjir merendam 1.150 rumah, 3 tempat ibadah, 1 sekolah, 80 hektare sawah, 60 hektare kebun, serta 70 hektare kawasan permukiman. Akses lalu lintas dilaporkan terputus total. Warga terdampak banjir tercatat menembus $1.032 \mathrm{KK} / 2.023$ jiwa. Dilaporkan 861 warga yang terpaksa mengungsi. (Rifki, 2021)

Banjir menimbulkan dampak buruk terhadap kesehatan masyarakat. Hal ini disebabkan oleh kondisi pasca banjir yang rawan menjadi faktor pemicu munculnya penyakit. Berbagai kondisi tersebut adalah (1) Berkembangnya vektor penyakit berupa hewan seperti tikus dan nyamuk;(2) Makanan seperti persediaan beras dan sayur mayur terkontaminasi; (3) Sumber air tercemar; (4) sampah berserakan; (5) Fasilitas kakus kurang; (6) Persediaan air bersih minim; dan (7) Fasilitas pengungsian buruk dan tidak sehat. Akibat dari kondisi lingkungan yang buruk tersebut adalah munculnya berbagai penyakit seperti Demam Berdarah Dengue (DBD), Diare, Infeksi Saluran Nafas Akut (ISPA), Leptospirosis, dan berbagai jenis penyakit kulit, Penyakit kulit disebabkan oleh mikroorganisme seperti bakteri, jamur, dan virus yang banyak terdapat di air banjir. Oleh karena itu, sebisa mungkin untuk menghindarkan kontak langsung dengan air banjir. Beberapa jenis 
penyakit kulit tersebut adalah panu, kutu air, kurap (disebabkan oleh jamur), selutis, bisul (disebabkan oleh bakteri) dan herpes (disebabkan virus) ( $R, 2014)$.

Tindakan/kegiatan yang sebaiknya perlu diperhatikan setelah terjadi banjir adalah (1) Menghindari kontak langsung dengan air banjir; (2) Menggunakan air matang/air kemasan untuk beraktifitas; (3) Untuk sementara, menghindari penggunaan air keran dan air sumur; (4) Identifikasi daerah bersih dan daerah terkontaminasi sekitar; dan (5) Membersihkan perabotan yang masih ingin digunakan dengan disinfektan. Untuk mengoptimalkan upaya penanggulangan masalah kesehatan pasca banjir maka diperlukan kerjasama yang baik dari semua pihak termasuk pemerintah, masyarakat, dan lembaga swadaya. (Ekpat, 2014) Pengabdian masyarakat ini bertujuan untuk melihat sejauh mana tingkat pengetahuan masyarakat tentang penyakit kulit akibat dari banjir. Desain dalam pengabdian kepada masyarakat ini adalah dengan menggunakan metode pengabdian kepada masyarakat deskripsi dengan pendekatan crossektional, menggunakan instrument berupa kuesioner. (dkk, 2018) Responden berjumlah 40 orang yang berasal dari Desa Liang julang blok Dukuh Domba kecamatan Kadipaten. Data yang dikumpulkan berupa data primer yang didapat dari kuesioner.

Target dalam pengabdian masyarakat ini adalah adanya peningkatan pengetahuan masyarakat dampak dari banjir terkait terjadinya berbagai penyakit kulit dan juga bekerjasama dengan puskesmas Kadipaten untuk pengobatan penyakit kulit. Sehingga setelah dilakukan penyuluhan dan pengobatan masyrakat dapat Kembali beraktifitas Kembali. (dkk M. s., 2019)

\section{Metode}

Pengabdian kepada masyarakat ini dilakukan pada bulan Februari 2021 di Desa Liang Julang Blok Dukuh Domba. Metode pengabdian kepada masyarakat dengan Pendidikan Kesehatan dengan seminar dan penyuluhan. Metode pelaksanaan kegiatan ini meliputi 4 tahap yaitu: perencanaan program,pelaksanaan program, observasi dan evaluasi (Gall, 2003) kegiatan evaluasi dilakukan pada awal kegiatan, proses kegiatan dan akhir kegiatan. Masalah yang dihadapai telah di temukan solusinya yaitu bekerjasama dengan pihak puskesmas untuk dilakukan pengobatan pada penyakit kulit yang terjadi akibat dari dampak banjir.kegiatan ini berlangsung dengan sangat baik dan lancar.

Evaluasi yang dilaksanakan pada awal kegiatan, proses kegiatan dan akhir kegiatan diantaranya :

1. Pre test : Dilaksanakan pada saat sebelum dilakukan penyuluhan yaitu dengan memberikan beberapa pertanyaan seputar penyakit kulit.

2. Proses : dilaksanakan pada saat penyampaiaan materi yaitu dengan memberikan pertanyaan kepada para peserta kemudian melihat keaktifan dalam menjawab pertanyaan

3. Post test : dilaksanakan setelah penyampaian materi. Yaitu dengan memberikan pertanyaan terkait penyakit kulit akibat dampak dari banjir dan penanganan pertama

4. Out come : pengetahuan dan sikap peserta meningkat terkait penanganan penyakit kulit dampak dari banjir dan penanganan pertama. (dkk, 2018)

\section{Hasil dan Pembahasan}

Pelaksanaan pengabdian kepada masyarakat berjalan dengan lancar dan antusis masyarakt dalam acara penyuluhan ini cukup baik ini terbukti dengan kehadiran peserta penyuluhan $100 \%$. Ini menandakan bahwa masyarakat menyambut baik atas kegiatan penyuluhan yang dilaksanakan. Kepala desa Liang julang dan perangkatnya menyambut baik dan antusis terhadap pelaksanaan pengabdian kepada masyrakat ini begitupun tokoh masyarakt dan tokoh agama ikut hadir memenuhi undangan. Banyak masukan dan pertanyaan yang diajukan oleh peserta maupun dari tim pengabdian kepada masyarakat (PKM), masukan yang diajukan oleh tim PKM terkait pencegahan penyakit dan penanganan penyakit pasca banjir selain dari penyakit kulit seperti penyakit deman berdarah, Infeksi saluran pernafasan atas, diare, dll. Peserta sudah cukup 
memahami Tindakan pencegahan dan penanganan pertama apabila terkena penyakit kulit dampak dari banjir. Dan masyarakt juga sudah memahami persiapan dan pertahanan Ketika banjir melanda.

Kendala yang dihadapi pada saat pelaksanaan kegiatan PKM ini adalah tempat pelaksanaannya dihalaman masjid sehingga suanananya panas dan mengurangi konsentrasi, sehingga ada beberapa peserta yang meninggalkan acara sebelum acaranya selesai.

Dari peserta yang hadir sebanyak 40 orang yang berjenis kelamin laki laki 12 orang dan yang berjenis kelamin perempuan 28 orang, sedangkan berdasarkan golongan umur anak anak 2 orang, remaja 2 orang, dewasa 8 orang, lansia 28 orang dan berdasarkan penyakit kulit nya gatal gatal dan kemerahan 20 orang, kurap 5 orang, kudis 15 orang ( berdasarkan data dari puskesmas Kadipaten)

(gambar 1,2,3)

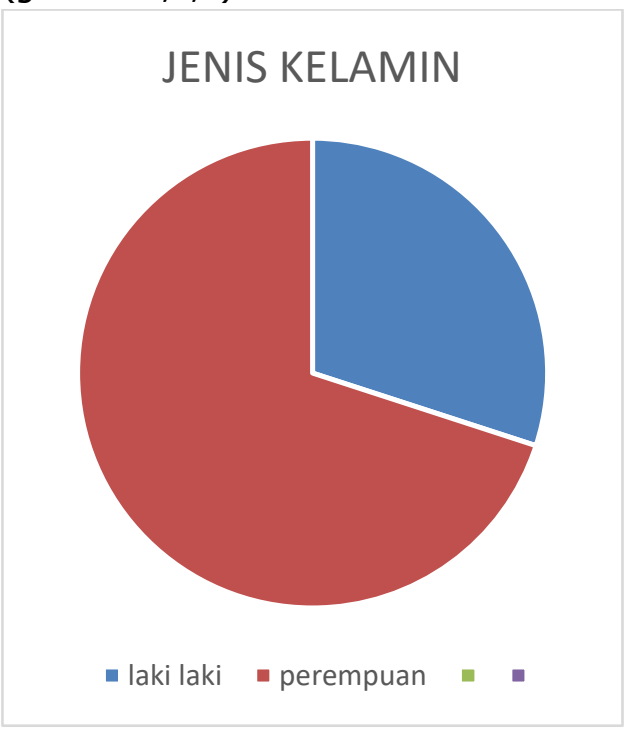

Gambar 1

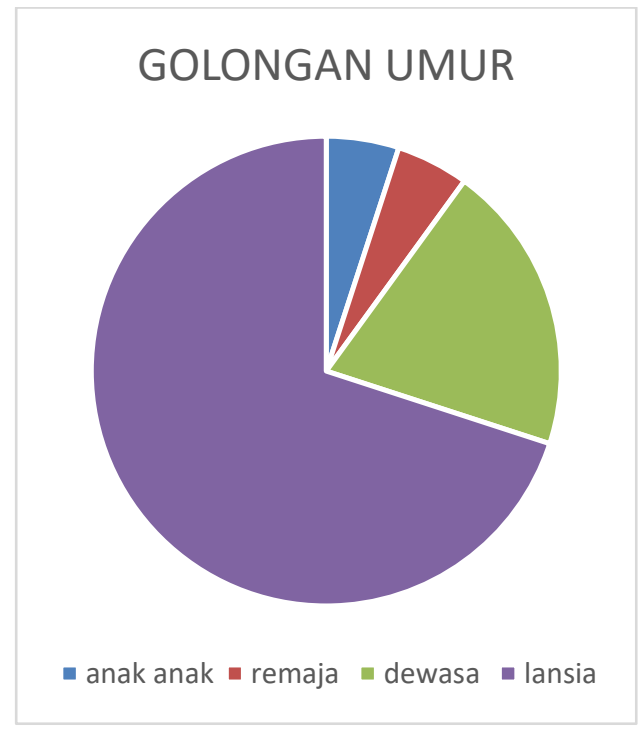

Gambar 2

\section{JENIS PENYAKIT KULIT}

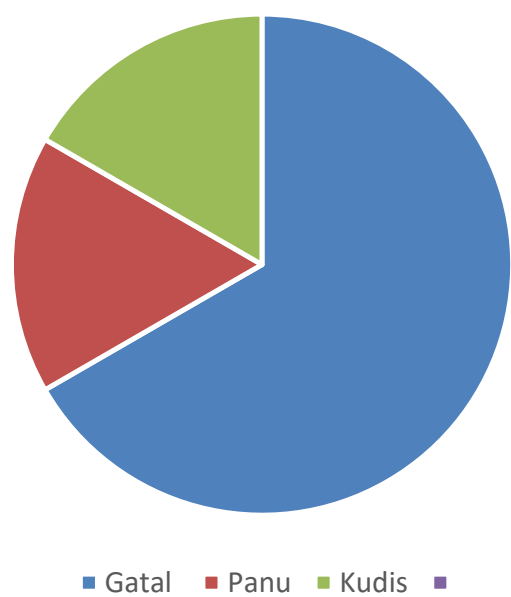

Gambar 3 
- Masyarakat mengalami bencana banjir.

- Banyak masyarakat yang mengalami penyakit kulit pasca banjir.

- Masyarakat belum tau cara penanganan awal penyakit kulit.

Metode kegiatan penyuluhan

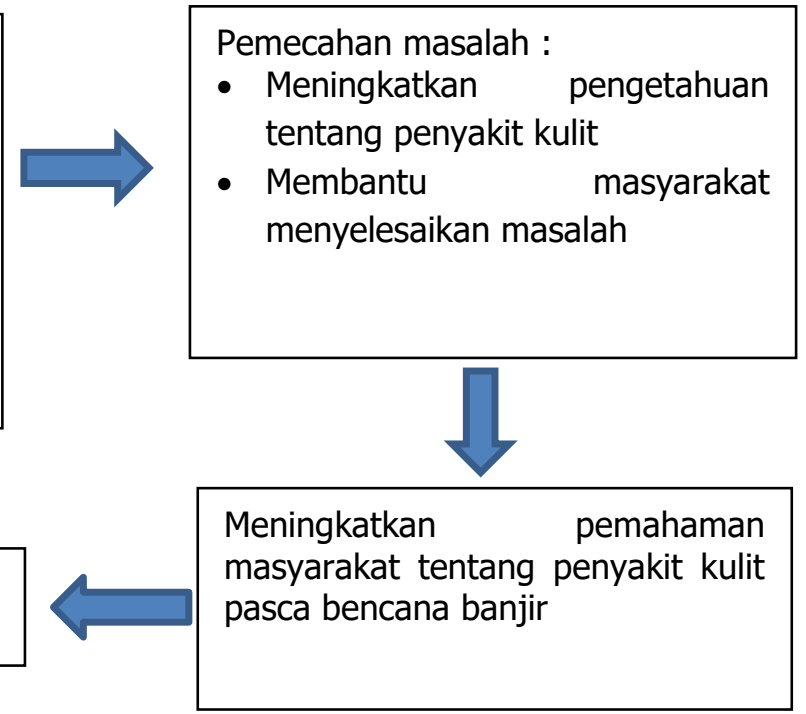

Gambar 1 Bagan metode pemecahan masalah

\section{Kesimpulan}

Penyuluhan dapat meningkatkan pengetahuan masyarakat tentang penyakit kulit pasca bencana banjir dan penanganan awal ketika sudah terjangkit penyakit kulit. Penyuluhan dilaksanakan di desa Liang Julang blok Dukuh Domba pada tanggal 13 Februari 2021 bertempat di halaman masjid berjalan dengan baik dan lancar, hal ini terbukti dengan kehadiran sebanyak $100 \%$.dan bekerjasama dengan pihak puskesmas Kadipaten untuk pengobtan penyakit kulit yang sudah terjangkit.

\section{Daftar Pustaka}

dkk, A. b. (2018). Peningkatan ketahanan masyarakat Benjeng terhadap korban bencana banjir. Jurnal layanan masyarakat Airlangga, 83-85.

dkk, M. s. (2019). PKM penyuluhan penggunaan antibiotik. Jurnal pengabidan kepada masyarakat, $297-301$.

Ekpat. (2014). Medikal . Jakarta: Flood water.

Gall, .. D. (2003). Educational reseach : An introdaction.7th Edn. Boston : Pearson Aducational. Educational reseach.

R, S. (2014). Macam macam Penyakit Akibat Banjir . Jakarta: Kabar 24.com .

Rifki, A. (2021). Peta Banjir Jawa Barat. Jakarta : Tempo . 